\title{
Peroxovanadate but not vanadate exerts insulin-like effects in human adipocytes
}

\author{
P. Lönnroth ${ }^{1}$, J. W. Eriksson ${ }^{1}$, B. I.Posner ${ }^{2}$ and U.Smith ${ }^{1}$ \\ ${ }^{1}$ Department of Medicine, University of Göteborg, Göteborg, Sweden \\ ${ }^{2}$ Department of Medicine, McGill University, Montreal, Canada
}

\begin{abstract}
Summary. Vanadate and peroxovanadate were recently reported to exert maximal or even supramaximal (peroxovanadate) insulin-like effects in rat adipocytes. To evaluate the response in human cells, isolated human adipocytes were exposed to insulin or various concentrations of vanadate $(0-10 \mathrm{mmol} / \mathrm{l})$ or peroxovanadate $(0-5 \mathrm{mmol} / \mathrm{l})$. Neither vanadate nor peroxovanadate affected ${ }^{125} \mathrm{I}$-insulin binding and insulin sensitivity. Vanadate exerted no apparent effect on ${ }^{14} \mathrm{C}$-U-glucose uptake, whereas $0.1 \mathrm{mmol} / 1$ peroxovanadate exerted a full insulin-like response $(p<0.001)$. No additive response was observed by combining either vanadate or
\end{abstract}

peroxovanadate with insulin. Peroxovanadate at $0.1 \mathrm{mmol} / \mathrm{l}$ was as effective as insulin in inhibiting isoproterenol-stimulated lipolysis. Neither peroxovanadate nor insulin-inhibited lipolysis stimulated by $\mathrm{N}^{6}$-monobutyryl-cAMP, an analogue which is not hydrolysed by the cAMP-phosphodiesterase. It is concluded that peroxovanadate, but not vanadate, elicits a full insulin-like response in human adipocytes.

Key words: Vanadate, peroxovanadate, adipose cells, lipolysis, glucose transport.
Traces of vanadate are found in most plants and mammalian tissues. Vanadate is also an essential nutrient [1], which stimulates mitogenic activity in cell cultures [2]. However, the physiological function of vanadate is still unclear (see [3]). The effects exerted by vanadate include inhibition of ion transport ATP-ases [4] and phosphotyrosine phosphatase [5]. In recent years, increasing interest has been focused on the insulin-like activity of vanadate in various tissues and cells [6]. Since insulin resistance in experimental animals may be reversed by the addition of vanadate to the drinking water [7-9], vanadate may be a useful tool for studying the mechanisms of insulin resistance. In addition, we recently demonstrated that vanadate treatment of rat adipocytes augments insulin binding and sensitivity both in normal and insulin-resistant cells [10]. The possible clinical use of vanadate in insulin-resistant states has also attracted great interest. In a recent study [11], it was demonstrated that vanadate in combination with $\mathrm{H}_{2} \mathrm{O}_{2}$ forms peroxovanadate and that both vanadate and peroxovanadate increase the insulin receptor tyrosine kinase and exert insulin-like effects in rat adipocytes. In the same study it was shown that peroxovanadate was more potent than vanadate [11]. This was also recently confirmed in muscle from insulin-resistant animals [12].
In the present study, the effect of vanadate and peroxovanadate was for the first time studied in normal human adipocytes isolated from the subcutaneous fat.

\section{Materials and methods}

Adipose tissue biopsies: Biopsies (3-5 g) of subcutaneous adipose tissue were removed from subjects undergoing elective surgery for cholelithiasis. The biopsies were obtained immediately after anaesthesia and placed in a vessel containing medium 199 (Statens Bakteriologiska Laboratorium, Stockholm, Sweden) at $37^{\circ} \mathrm{C}$. The subjects were otherwise healthy and none was taking any regular medication. Their informed consent was obtained and the study was approved by the Ethics Committee of the University of Göteborg.

Isolation of adipose cells: Dissected tissue pieces $(\sim 5 \mathrm{mg})$ were incubated at $37^{\circ} \mathrm{C}$ in medium 199 containing $4 \%$ bovine albumin (Sigma, St. Louis, Mo., USA) and $1 \mathrm{mg} / \mathrm{ml}$ collagenase (Sigma) in a shaking water bath. After approximately $50 \mathrm{~min}$, liberated cells were filtered through a nylon mesh and washed four times in fresh albumin-containing medium containing $1 \mathrm{U} / \mathrm{ml}$ adenosine deaminase (ADA; Boehringer Mannheim, Mannheim, FRG).

Lipolysis: Isolated cells, lipocrit $1-3 \%$, were incubated at $37^{\circ} \mathrm{C}$ in the presence of $1 \mathrm{U} / \mathrm{ml}$ adenosine deaminase (ADA) with or without isoproterenol, $\mathrm{N}^{6}$-monobutyryl-cAMP (Sigma), insulin (Novo Nor- 

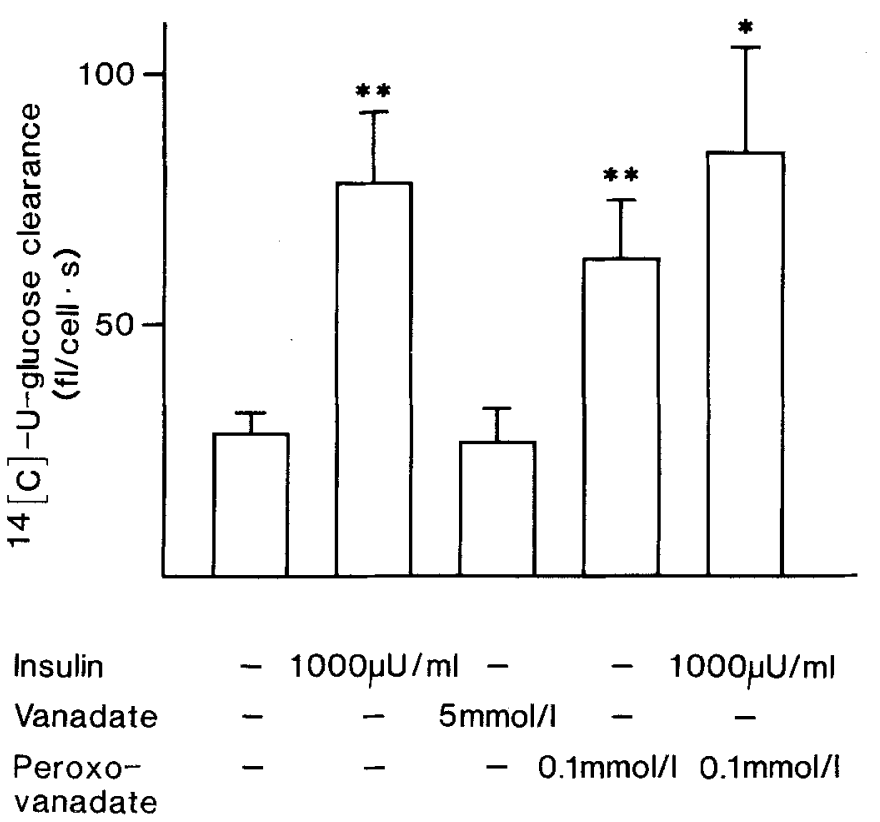

Fig. 1. $\left[{ }^{14} \mathrm{C}\right]-\mathrm{U}$-glucose $(0.5 \mathrm{mmol} / \mathrm{l})$ uptake by human adipocytes in the absence or presence of insulin $(1000 \mu \mathrm{U} / \mathrm{ml})$, vanadate $(5 \mathrm{mmol} / \mathrm{l})$ and peroxovanadate $(0.1 \mathrm{mmol} / \mathrm{l})$. Data are expressed as means \pm SE, $n=9-14 .{ }^{*} p<0.01,{ }^{* *} p<0.001$

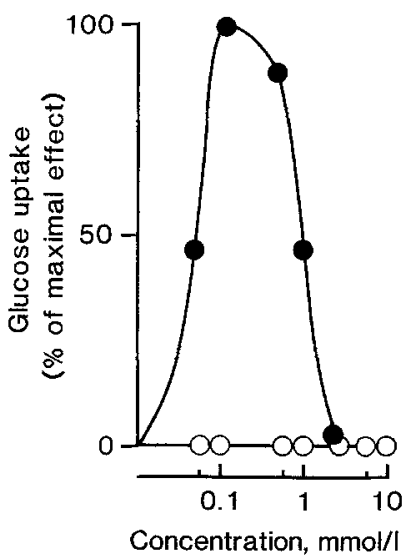

Fig. 2. The effect of different concentrations of peroxovanadate $(-\mathbf{0})$ or vanadate $(\mathrm{O}-\mathrm{O})$ on $\left[{ }^{14} \mathrm{C}\right]-\mathrm{U}$-glucose uptake by human adipocytes. Data are expressed as the mean percentage of the maximal response exerted by peroxovanadate $(100 \%) \cdot n=3$

disk, Copenhagen, Denmark), vanadate or peroxovanadate at the indicated concentrations for $1 \mathrm{~h}$. The incubation was stopped by centrifuging the cells through silicone oil. The glycerol content of the incubation medium was analysed [13] and taken as an index of lipolysis. Cell size and number were measured as previously described [14].

${ }^{14} \mathrm{C}$-U-glucose uptake: Cellular uptake of ${ }^{14} \mathrm{C}-\mathrm{U}$-glucose (New England Nuclear, Boston, Mass., USA) at a tracer concentration $(0.3 \mathrm{mmol} / \mathrm{L}, 0.2 \mu \mathrm{Ci} /$ tube $)$ was measured during $1-\mathrm{h}$ incubation of cells in glucose-free medium following pre-incubation in the absence or presence of insulin for $15 \mathrm{~min}$. After separation from the incubation medium, the cells were put into scintillation fluid and the radioactivity counted. The cellular clearance of medium glucose was calculated according to the formula:

$($ cpm cells $) /($ cpm medium $) \times($ cell number $) \times \mathrm{s}$

and taken as an index of the rate of glucose uptake [15].

${ }^{125} \mathrm{I}$-insulin binding: Following the addition of $2 \mathrm{mmol} / \mathrm{KCN}$ (to stop receptor cycling) $200 \mathrm{pg} / \mathrm{ml}^{125} \mathrm{I}$-insulin $(60-90 \mathrm{nCi} /$ tube, Novo Nordisk) and $0-0.7 \mu \mathrm{mol} / 1$ unlabelled insulin was added to cells incu- bated as described above. After $2 \mathrm{~h}$ at $16^{\circ} \mathrm{C}$ the cells were separated from the incubation medium and radioactivity counted. Tracer bound in the presence of $0.7 \mu \mathrm{mol} / /$ unlabelled insulin was considered non-specific and was subtracted.

Preparation of vanadate and peroxovanadate: Sodium orthovanadate (Sigma) was dissolved in medium 199 to a final concentration of $10 \mathrm{mmol} / \mathrm{l}$ and $\mathrm{pH}$ adjusted to 7.4 with $1 \mathrm{~mol} / \mathrm{l} \mathrm{HCl}$ at $37^{\circ} \mathrm{C}$ [11]. Peroxovanadate was generated by mixing $1 \mathrm{mmol} / 1 \mathrm{H}_{2} \mathrm{O}_{2}$ and $10 \mathrm{mmol} / \mathrm{l}$ vanadate. After $15 \mathrm{~min}$ at room temperature, catalase (Sigma) was added to a final concentration of $200 \mu \mathrm{g} / \mathrm{ml}$ for a further $15 \mathrm{~min}$ to remove free $\mathrm{H}_{2} \mathrm{O}_{2}[11]$.

\section{Statistical analysis}

The statistical significance of differences was tested with Student's $t$-test for paired observations.

\section{Results}

\section{Glucose uptake}

Figure 1. shows the effect of insulin, vanadate and peroxovanadate on ${ }^{14} \mathrm{C}$-U-glucose uptake. Insulin at $1000 \mu \mathrm{U} / \mathrm{ml}$ stimulated ${ }^{14} \mathrm{C}$-U-glucose uptake approximately 2.5 -fold and $0.1 \mathrm{mmol} / \mathrm{l}$ peroxovanadate completely mimicked this effect of insulin. Surprisingly, vanadate alone was ineffective at any concentration tested $(0.05-10 \mathrm{mmol} / \mathrm{l})$. No additive response was seen by combining $0.1 \mathrm{mmol} / \mathrm{l}$ peroxovanadate and $1000 \mu \mathrm{U} / \mathrm{ml}$ insulin. Control experiments confirmed that sodium orthovanadate alone exerted a full insulin-like effect in rat adipocytes (data not shown).

The dose-response curve for the stimulatory effect of peroxovanadate on ${ }^{14} \mathrm{C}$-U-glucose uptake is shown in Figure 2. The half-maximal effect of peroxovanadate was seen at $0.05 \mathrm{mmol} / \mathrm{l}$. The dose-response curve was markedly biphasic and basal levels of ${ }^{14} \mathrm{C}$-U-glucose uptake were seen at peroxovanadate concentrations of $2 \mathrm{mmol} / \mathrm{l}$ and above. Vanadate did not exert any response at any concentration.

The dose-response curve for the effect of insulin on ${ }^{14} \mathrm{C}$-U-glucose uptake was not altered by either vanadate ( 2 or $5 \mathrm{mmol} / \mathrm{l}$ ) or peroxovanadate $(0.05$ or $0.1 \mathrm{mmol} / \mathrm{l}$ ). ${ }^{125}$ I-insulin binding was not consistently changed by either of these agents (data not shown).

\section{Antilipolytic effect}

Neither insulin nor vanadate alone or in combination with $\mathrm{H}_{2} \mathrm{O}_{2}$ exerted any antilipolytic effect in the absence of lipolytic agents (data not shown). When lipolysis was stimulated by $\mathrm{N}^{6}$-monobutyryl cAMP, a cAMP analogue which is not hydrolysed by the phosphodiesterase [16], no antilipolytic effect was exerted by any of the three agents (Fig. 3). However, when lipolysis was stimulated by isoproterenol $(1 \mu \mathrm{mol} / 1)$ insulin decreased the lipolysis rate by about $50 \%$. Peroxovanadate at $2 \mathrm{mmol} / \mathrm{l}$ was equally effective, whereas vanadate was ineffective at any concen- 

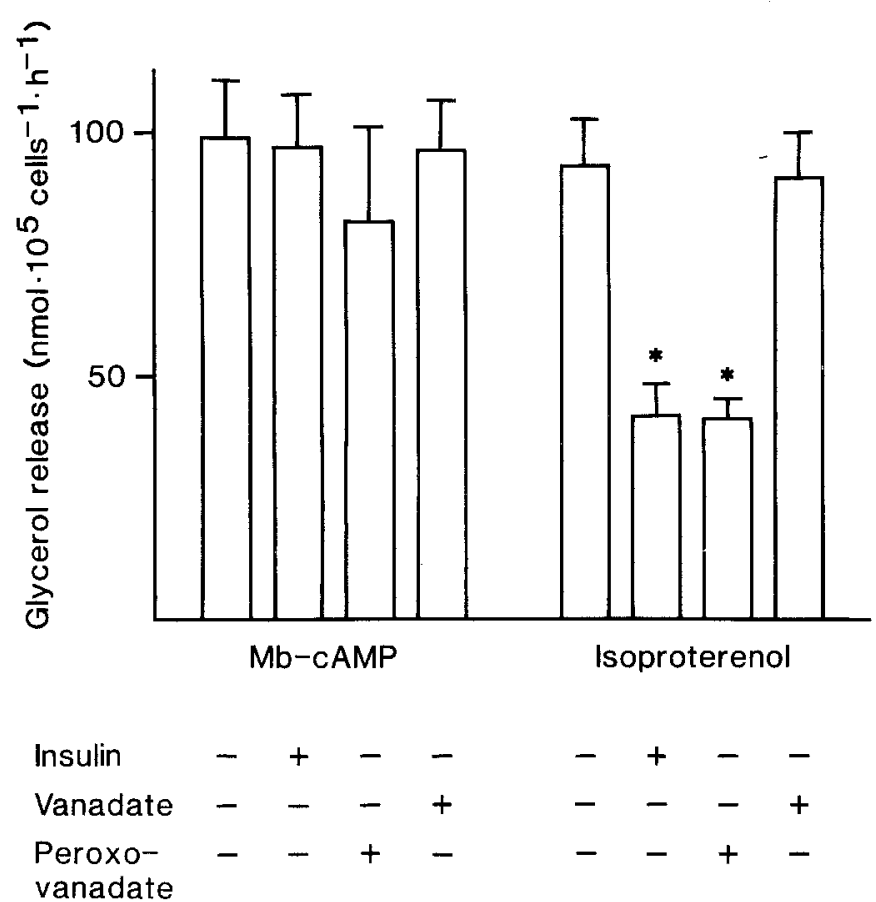

Fig.3. Glycerol release from human adipocytes in the presence of lipolytic ( $2 \mathrm{mmol} / 1 \mathrm{~N}^{6}$-monobutyryl-cAMP, $1 \mu \mathrm{mol} / \mathrm{l}$ isoproterenol) and antilipolytic $(1000 \mu \mathrm{U} / \mathrm{ml}$ insulin, $5 \mathrm{mmol} / \mathrm{l}$ vanadate, $2 \mathrm{mmol} / \mathrm{l}$ peroxovanadate) agents as indicated. Data are expressed as means $\pm \mathrm{SE}, n=4 . * p<0.01$

tration tested, up to concentrations as high as $10 \mathrm{mmol} / \mathrm{l}$ (Fig.3).

\section{Discussion}

In this study the effect of vanadate and peroxovanadate was tested for the first time in a human cell type, the human subcutaneous adipocyte. The data clearly show that, unlike the rat adipocyte, these cells are unresponsive to vanadate under these conditions. Neither insulin responsiveness nor sensitivity was altered by the addition of vanadate and vanadate itself did not exert an insulin-like activity. To exclude the possibility that this was due to problems with the preparation of the vanadate solution, control experiments were performed with isolated rat adipocytes. These clearly showed that the vanadate used exerted a normal insulin-like effect on ${ }^{14} \mathrm{C}$-U-glucose uptake in these cells (data not shown). Thus, it may be concluded that, under the present conditions, vanadate was not effective in human adipocytes. However, it should be noted that the insulin-like activity was only assessed in acute experiments and the present data do not therefore exclude the possibility that vanadate may have long-term effects as previously demonstrated in experimental animals [7-9].

Although vanadate does not exert insulin-like effects in human adipocytes, these cells appear to be readily responsive to peroxovanadate. A full insulin-like response was exerted at low concentrations of peroxovanadate when the effects of ${ }^{14} \mathrm{C}-\mathrm{U}$-glucose uptake and lipolysis were measured. However, no additive effect of peroxovanadate was exerted in combination with a maximal concentration of insulin. This is in contrast to the recent study with rat adipocytes of Kadota et al. [17], where peroxovanadate further increased the recruitment of insulinlike growth factor (IGF) II-receptors to the cell surface in the presence of a maximal concentration of insulin [17]. Furthermore, human and rat adipose cells seem to respond differently to peroxovanadate since, as demonstrated in the present study, the dose-response curve for peroxovanadate was markedly biphasic in human fat cells and the insulin-like activity was seen only over a narrow concentration range. This has not been reported with rat adipocytes $[11,17]$. The reason for this biphasic response in human fat cells is not fully clear. However, control studies with human fat cells in our laboratory have shown that vanadate dose-dependently inhibits the effect of peroxovanadate (data not shown). Thus, free vanadate seems to compete with peroxovanadate at the appropriate sites of action. It is unlikely that high concentrations of peroxovanadate exerts a toxic effect since the antilipolytic effect of pervanadate remained even at $2 \mathrm{mmol} / \mathrm{l}$.

The mechanism by which vanadate exerts its insulinlike effects in rat adipocytes is not clear [3]. However, the demonstration that insulin binding to the insulin receptor leads to autophosphorylation of the receptor $\beta$-subunit [18] which subsequently expresses tyrosine kinase activity [19], suggests an important effect of the phosphotyrosine phosphatase inhibition for the action of vanadate. In agreement with this possibility, it has been shown that activation of the insulin receptor tyrosine kinase by vanadate correlates with the insulin effect on IGF-II receptor binding $[11,17]$. In contrast, such a relationship between the receptor tyrosine kinase and the antilipolytic effect of vanadate was not evident in two recent studies $[20,21]$. Thus, it is not clear that vanadate exerts its insulin-like activity by increasing the insulin receptor tyrosine kinase activity.

An alternative explanation for the insulin-like effect of vanadate may be that vanadate stimulates NADH oxidase and, thus, increases $\mathrm{H}_{2} \mathrm{O}_{2}$ formation inside the cells [22]. $\mathrm{H}_{2} \mathrm{O}_{2}$ is capable of exerting insulin-like activity in adipocytes [23]. Moreover, since vanadate readily enters the cells intracellular formation of peroxovanadate may take place. However, such an effect is then obviously deficient in human fat cells since they are unresponsive to vanadate alone. Whatever the mechanism of action of peroxovanadate, this agent is more efficient than vanadate as a mimic of the effects of insulin in human adipocytes. It should be noted, however, that the mechanism by which peroxovanadate and insulin exert their effects in human adipocytes may share the same signalling pathway(s) since no additive effect in combination with insulin was seen. Furthermore, peroxovanadate effectively inhibited catecholamine-stimulated lipolysis, as insulin does, but did not inhibit lipolysis stimulated by the non-hydrolysable cAMP analogue $\mathrm{N}^{6}$-monobutyryl-cAMP, suggesting that the antilipolytic effect by both agents is exerted by the activation of the phosphodiesterase [24].

It was recently reported that insulin binding to rat adipocytes is increased in the presence of vanadate [25]. Ex- 
periments on rat adipocytes in our laboratory have shown that vanadate increased the number of binding sites for insulin at the cell surface and, in parallel, shifted the doseresponse curve for insulin to the left [10]. However, in the present study with human fat cells no such effect was exerted by vanadate or, consistently, by peroxovanadate.

In summary, the present study shows that no insulinlike effect is exerted by vanadate in human subcutaneous adipocytes, whereas peroxovanadate is highly effective, giving a full insulin-like response at a low concentration. Future investigations focused on mechanisms of action as well as the long-term effect of peroxovanadate in vivo in animal models of diabetes or other manifestations of insulin resistance would be of obvious interest. However, such studies would require the availability of stable peroxovanadate preparations. Such compounds are now being developed and should provide us with useful tools to explore the insulin signalling mechanism.

Acknowledgements. This study was supported by grants from the Swedish Medical Research Council (project number B-3506), Svenska Diabetesförbundet, Svenska Hoechst, Nordisk Insulinfond and Socialstyreisens fond. The skillful technical assistance of Ms. B. Carlander, Ms. H.Persson and Ms. B.Karlsson-Svalstedt is gratefully acknowledged.

\section{References}

1. Nechay BR (1984) Mechanisms of action of vanadium. Ann Rev Pharmacol Toxicol 24: 501-524

2. Hori C, Oka T (1980) Vanadate enhances the stimulatory action of insulin on DNA synthesis in cultured mouse mammary gland. Biochim Biophys Acta 610: 235-240

3. Degani H, Gochin M, Karlish SJD, Schechter Y (1981) Electron paramagnetic resonance studies and insulin-like effects of vanadate in rat adipocytes. Biochemistry 20: 5795-5799

4. Nechay BR, Nanninga LB, Nechay PSE et al. (1986) Role of vanadate in biology. Fed Proc 45: 123-132

5. Swarup G, Speeg KV Jr, Cohen S, Garbers DL (1982) Phosphotyrosyl-protein phosphatase of TCRC-2 cells. J Biol Chem 257: 7298-7301

6. Schechter Y, Amir S, Meyerovitch J (1988) The insulin-like metabolic effects of vanadate; possible implications to the future care of diabetes. Diab Nutr Metab. 1:1-5

7. Heyliger CE, Tahiliani AG, McNeill JH (1985) Effect of vanadate on elevated blood glucose and depressed cardiac performance of diabetic rats. Science 227: 1474-1477

8. Pederson RA, Ramanadham S, Buchan AMJ, McNeill JH (1989) Long-term effects of vanadyl treatment of streptozotocin-induced diabetes in rats. Diabetes 38: 1390-1395

9. Blondel O, Bailbe D, Portha B (1989) In vivo insulin resistance in streptozotocin-diabetic rats - evidence for reversal following oral vanadate treatment. Diabetologia 32: 185-190

10. Eriksson JW, Lönnroth P, Smith U (1992) Vanadate increases cell surface insulin binding and improves insulin sensitivity in both normal and insulin-resistant rat adipocytes. Diabetologia 35: $510-516$
11. Kadota S, Fanturs IG, Deragon G, Guyda HJ, Hersh B, Posner BI (1987) Peroxide(s) of vanadium: a novel and potent insulinmimetic agent which activates the insulin receptor kinase. Biochem Biophys Res Commun 147: 259-266

12. Leighton B, Cooper GJS, DaCosta C, Foot EA (1991) Peroxovanadates have full insulin-like effects on glycogen synthesis in normal and insulin-resistant skeletal muscle. Biochem J 276: 289-292

13. Laurell S, Tibbling G (1966) An enzymatic fluorimetric micromethod for the determination of glycerol. Clin Chim Acta 13: 317-322

14. Smith U, Sjöström L, Björntorp P (1972) Comparison of two methods for determining human adipose cell size. J Lipid Res 13: $822-824$

15. Kashiwagi A, Verso MA, Andrews J, Vasquez B, Reaven G, Foley JE (1983) In vitro insulin resistance of human adipocytes isolated from subjects with noninsulin-dependent diabetes mellitus. J Clin Invest 72: 1246-1252

16. Beebe SI, Holloway R, Rannels SR, Corbin ID (1984) Two classes of cAMP analogs which are selective for the two different cAMP-binding sites of type II protein kinase demonstrate synergism when added together to intact adipocytes. J Biol Chem 259:3539-3547

17. Kadota S, Fantus IG, Deragon G, Guyda HJ, Posner BI (1987) Stimulation of insulin-like growth factor II receptor binding and insulin receptor kinase activity in rat adipocytes. I Biol Chem 262: $8252-8256$

18. Kasuga M, Fujita-Yamaguchi Y, Blithe DL, White MF, Kahn CR (1983) Characterization of the insulin receptor kinase purified from human placental membranes. J Biol Chem 258: 1097310980

19. Rosen OM, Herrera R, Olowe Y, Petruzzeli LM, Cobb MH (1983) Phosphorylation activates the insulin receptor tyrosine protein kinase. Proc Natl Acad Sci USA 80: 3237-3240

20. Mooney RA, Bordwell KL, Luhowskyj S, Casnellie JE (1989) The insulin-like effect of vanadate on lipolysis in rat adipocytes is not accompanied by an insulin-like effect on tyrosine phosphorylation. Endocrinology 124: 422-429

21. Strout HV, Vicario PP, Saperstein R, Slater EE (1989) The insulin-mimetic effect of vanadate is not correlated with insulin receptor tyrosine kinase activity nor phosphorylation in mouse diaphragm in vivo. Endocrinology 124: 1918-1924

22. Maj JM, de Haën C (1979) Insulin-stimulated intracellular hydrogen peroxide production in rat epididymal fat cells. J Biol Chem 254:2214-2220

23. Czech MP, Lawrence JC Jr, Lynn WS (1974) Hexose transport in isolated brown fat cells. J Biol Chem 249: 5421-5427

24. Lönnroth P, Smith U (1986) The antilipolytic effect of insulin in human adipocytes requires activation of the phosphodiesterase. Biochem Biophys Res Commun 141: 1157-1161

25. Fantus IG, Ahmad F, Deragon G (1990) Vanadate augments insulin binding and prolongs insulin action in rat adipocytes. Endocrinology $127: 2716-2725$

Received: 7 July 1992

and in revised form: 24 September 1992

Dr. P. Lönnroth

Department of Medicine

Sahlgren's Hospital

S-413 45 Göteborg

Sweden 